\section{Fertilization and Growth of Field-grown Citrus Nursery Trees in Florida}

\author{
Frederick S. Davies ${ }^{1}$ and Glenn Zalman
}

AdDitional INDEX wORDs. Citrus sinensis, nutrition, nitrogen

Summary. The objective of this study was to determine the effects of various levels of nitrogen ( $\mathrm{N}$ ) on growth of 'Hamlin' orange (Citrus sinensis) trees on Carrizo citrange (C. sinensis $\times$ Poncirus trifoliata) rootstock in a field nursery. Newly budded liners were obtained from commercial nurseries and received from 0 to $3976 \mathrm{~kg} \mathrm{~N}$ per treated hectare annually $(8 \mathrm{~N}-0 \mathrm{P}-6.6 \mathrm{~K})$ in 14 applications per season. Tree trunk diameter, height, and dry weight were measured in two separate experiments. Total dry weight and trunk diameter were greatest for trees receiving $794 \mathrm{~kg} \cdot \mathrm{ha}^{-1} \mathrm{~N}$ annually during both seasons. However, annual $\mathrm{N}$ rates more than $1589 \mathrm{~kg} \cdot \mathrm{ha}^{-1}$ reduced trunk diameters and dry weight compared with the optimum $\mathrm{N}$ rate during both seasons. Leaf $\mathrm{N}$ concentration and $\mathrm{N}$ rate were positively correlated in both seasons, but leaf $\mathrm{N}$ concentration was poorly correlated with tree trunk diameter and dry weight. Therefore, very high rates of $\mathrm{N}$ fertilization may actually reduce 'Hamlin' orange tree growth in field nurseries when growing in an Arredondo fine sand.

$\mathrm{F}$ lorida citrus nurseries produce more than 2 million trees annually (Kessinger, 2005). Citrus trees were traditionally produced either in field nurseries ( $65 \%$ of total) or in greenhouses (35\% of total). However, with the return of citrus canker (Xanthomonas axonopodis pv. citri) and the introduction of citrus greening (Candidatus liberibacter) to Florida, new nurseries now must grow trees in greenhouses in isolated areas. Nevertheless, field nurseries currently are still important sources of citrus trees in Florida.

Adequate nutrition is essential for production of high-quality citrus nursery trees, but application rates, frequencies of application, and nitrogen $(\mathrm{N})$ sources vary greatly among citrus nurseries worldwide. For example, annual $\mathrm{N}$ rates in Florida citrus nurseries varied from 1174 to 3222 $\mathrm{kg} \cdot \mathrm{ha}^{-1}$, with less than $20 \%$ of the applied $\mathrm{N}$ being recovered in leaves (Castle and Rouse, 1990).

Optimum fertigation (liquid $\mathrm{N}$ ) rates have been determined for the greenhouse, but not for field nurseries. Maust and Williamson (1991) found that critical $\mathrm{N}$ concentration ranged from 15 to $20 \mathrm{mg} \cdot \mathrm{L}^{-1}$ applied daily in $1.0 \mathrm{~L}$ water, and high $\mathrm{N}$ rates actually decreased tree growth. In contrast, Guazzelli et al. (1996)

Department of Horticultural Sciences, P.O. Box 110690, University of Florida, Gainesville, FL 32611

${ }^{1}$ Corresponding author. E-mail: fsd@ufl.edu. observed that the optimum $\mathrm{N}$ rate in solution was $165 \mathrm{mg} \cdot \mathrm{L}^{-1}$ or about $0.5 \mathrm{~L} \mathrm{~N} /$ tree annually. Differences in media types used likely resulted in differential responses in the two studies.

Only general guidelines are available concerning optimum $\mathrm{N}$ rates for field citrus nurseries. Recommended annual $\mathrm{N}$ rates for field nurseries range from 555 to $1110 \mathrm{~kg} \cdot \mathrm{ha}^{-1}$ (Bridges and Youtsey, 1977; Tucker and Youtsey, 1980), but some surveys suggested that rates as high as 2500 $\mathrm{kg} \cdot \mathrm{ha}^{-1}$ have been used in the past (Castle and Rouse, 1990).

The objective of this study was to determine the relationship between annual $\mathrm{N}$ rate and growth of 'Hamlin' orange nursery trees in the field. In addition, leaf samples were collected and $\mathrm{N}$ concentration analyzed to determine whether there is a correlation between $\mathrm{N}$ application rate, leaf $\mathrm{N}$ concentration, and growth in the field nursery.

\section{Materials and methods}

SEASON 1. Newly budded, barerooted 'Hamlin' orange trees on Carrizo citrange rootstock were obtained from a commercial nursery in Lithia, FL. The buds had just begun growing and all trees were very uniform in size $(\approx 4 \mathrm{~mm}$ in diameter $)$. Trees were planted in a field nursery at the Fifield Farm in Gainesville, FL, on 20 May 1998. Trees were planted in double rows at $30 \mathrm{~cm}$ between rows and $10 \mathrm{~cm}$ between trees within the row. Double rows were spaced $90 \mathrm{~cm}$ apart, which is a standard field nursery spacing for citrus in Florida. Trees were irrigated for $2 \mathrm{~h}$ daily using overhead sprinklers for 2 weeks after planting until they were established. Soil type was an Arredondo fine sand (loamy siliceous, hyperthermic, Grossarenic Paleudults).

The experimental site was divided into 48 six-tree blocks, which served as experimental units (replications). Each replicate was randomly assigned one of six $\mathrm{N}$ rates: $0,22.7$, $45.9,68.1,90.8$, and $113.5 \mathrm{~g} \mathrm{~N} /$ tree annually. This translated to 0,794 , $1589,2384,3179$, and $3976 \mathrm{~kg} \mathrm{~N}$ per treated hectare annually. These rates were based on previous fertilizer recommendations for Florida field nurseries as described earlier. A completely randomized design was used with 12 replications/treatment.

Granular fertilizer [ $8 \mathrm{~N}-0 \mathrm{P}-6.6 \mathrm{~K}$ (4\% ammonia, $4 \%$ nitrate)] was broadcast uniformly over each replicate at 2 -week intervals from 11 June until 20 Nov. (14 applications). No phosphorus (P) was added because levels were optimum in the soil, as is the case in many soils in central Florida.

Measurements. Trunk diameter was measured monthly using calipers for the center two trees of each six-tree replicate at $25 \mathrm{~cm}$ above the

\begin{tabular}{llll}
\hline $\begin{array}{l}\text { Units } \\
\begin{array}{l}\text { To convert U.S. to SI, } \\
\text { multiply by }\end{array}\end{array}$ & U.S. unit & SI unit & $\begin{array}{l}\text { To convert SI to U.S., } \\
\text { multiply by }\end{array}$ \\
\hline 0.4047 & acre(s) & $\mathrm{ha}$ & 2.4711 \\
3.7854 & gal & $\mathrm{L}$ & 0.2642 \\
2.54 & inch(es) & $\mathrm{cm}$ & 0.3937 \\
25.4 & inch $(\mathrm{es})$ & $\mathrm{mm}$ & 0.0394 \\
0.4536 & $\mathrm{lb}$ & $\mathrm{kg}$ & 2.2046 \\
1.1209 & $\mathrm{lb} / \mathrm{acre}$ & $\mathrm{kg} \cdot \mathrm{ha}^{-1}$ & 0.8922 \\
28.3495 & $\mathrm{oz}$ & $\mathrm{g}$ & 0.0353 \\
0.001 & $\mathrm{ppm}$ & $\mathrm{g} \cdot \mathrm{L}^{-1}$ & 1000 \\
1 & $\mathrm{ppm}$ & $\mathrm{mg} \cdot \mathrm{L}^{-1}$ & 1 \\
$\left({ }^{\circ} \mathrm{F}-32\right) \div 1.8$ & ${ }^{\circ} \mathrm{F}$ & ${ }^{\circ} \mathrm{C}$ & $\left(1.8 \times{ }^{\circ} \mathrm{C}\right)+32$
\end{tabular}


bud union. Tree height was also measured monthly using a measuring stick. Time and duration of each growth flush were recorded. The center two trees in each replicate were harvested on 10 Dec. 1998, and dry weights were determined for each tree.

SEAson 2. Newly budded 'Hamlin' orange trees on Carrizo citrange rootstock were obtained from a second, different commercial nursery in Lithia, FL, on 15 Mar. 1999. Trees were in containers and were very uniform in size $(\approx 1.5 \mathrm{~mm}$ in diameter $)$, and buds had just begun growing. Trees were planted from 29 Mar. to 2 Apr. in the southern portion of the same nursery used in 1998. Tree spacing, soil type, annual $\mathrm{N}$ rates, $\mathrm{N}$ sources, and experimental design were the same as used during season 1 .

Measurements. Trunk diameters were measured monthly for the two center trees in each six-tree replicate from 20 Apr. to 29 Dec. 1999. The center two trees were harvested on 22 to 29 May 2000, and dry weights were determined.

LEAF ANALYSIS. One fully expanded spring flush leaf was taken from each of the six trees for each replicate on 12 Aug. 1998 (season 1) and 2 Dec. 1999 (season 2). The leaf samples from each replication were combined and taken to the laboratory. Leaves were washed, oven dried at $70{ }^{\circ} \mathrm{C}$, ground, and extracted as described previously (Maurer and Davies, 1995). Samples were analyzed for leaf $\mathrm{N}$ concentration at the University of Florida Analytical Research Laboratory using an argon spectrophotometer.

Statistical analysis. Trunk diameter and height data were analyzed within each season by repeatedmeasures analysis (SAS 9.13 Institute, Cary, NC) and dry weights by regression analysis using SigmaPlot v10.0 and TableCurve 2D v5.01 software (SYSTAT Software, Richmond, CA).

Cultural practices. Trees were irrigated in both experiments based on soil water deficit (SWD) as determined using a neutron probe (Troxler, Raleigh, NC) (Marler and Davies, 1990). Three aluminum access tables were placed throughout the entire planting at a depth of 37 $\mathrm{cm}$. Readings were taken about every third day if no rain had occurred at $20-$ and $37-\mathrm{cm}$ depths. When the mean readings of the three tubes reached one-third SWD, trees were irrigated for $1.5 \mathrm{~h}$ using overhead sprinklers. This irrigation duration was sufficient to bring the soil to field capacity.

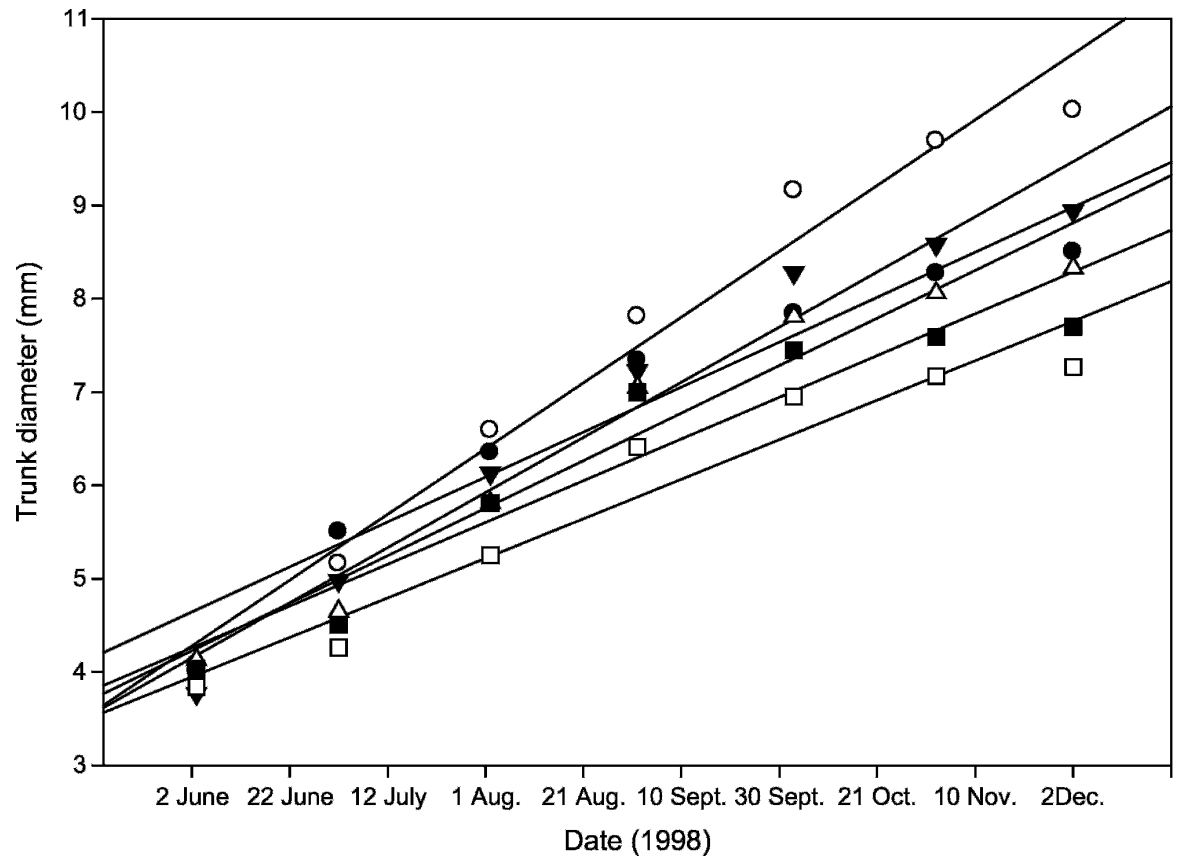

Fig. 1. Nitrogen (N) rate effects on trunk diameter of 'Hamlin' orange trees in a field nursery in $1998(n=12)$. Annual $N$ rates are given in kilograms per treated hectare. ( $\square), 0 \mathrm{~kg} \cdot \mathrm{ha}^{-1} \mathrm{~N}, \mathrm{y}=4.64+0.024 \mathrm{x}, r^{2}=0.93 ;(\bigcirc), 794 \mathrm{~kg} \cdot \mathrm{ha}^{-1} \mathrm{~N}$, $\mathrm{y}=4.27+0.035 \mathrm{x}, r^{2}=0.97 ;(\nabla), 1589 \mathrm{~kg} \cdot \mathrm{ha}^{-1} \mathrm{~N}, \mathrm{y}=4.15+0.030 \mathrm{x}, r^{2}=0.96$; $(\triangle) 2384 \mathrm{~kg} \cdot \mathrm{ha}^{-1} \mathrm{~N}, \mathrm{y}=4.22+0.025 \mathrm{x}, r^{2}=0.95 ;(\bullet), 3179 \mathrm{~kg} \cdot \mathrm{ha}^{-1} \mathrm{~N}$, $\mathrm{y}=4.25+0.022 \mathrm{x}, r^{2}=0.91 ;(\square), 3976 \mathrm{~kg} \cdot \mathrm{ha}^{-1} \mathrm{~N}, \mathrm{y}=3.94+0.021 \mathrm{x}, r^{2}=0.93$. $\left(1 \mathrm{~kg} \cdot \mathrm{ha}^{-1}=0.8922 \mathrm{lb} /\right.$ acre; $\left.1 \mathrm{~mm}=0.0394 \mathrm{inch}\right)$.

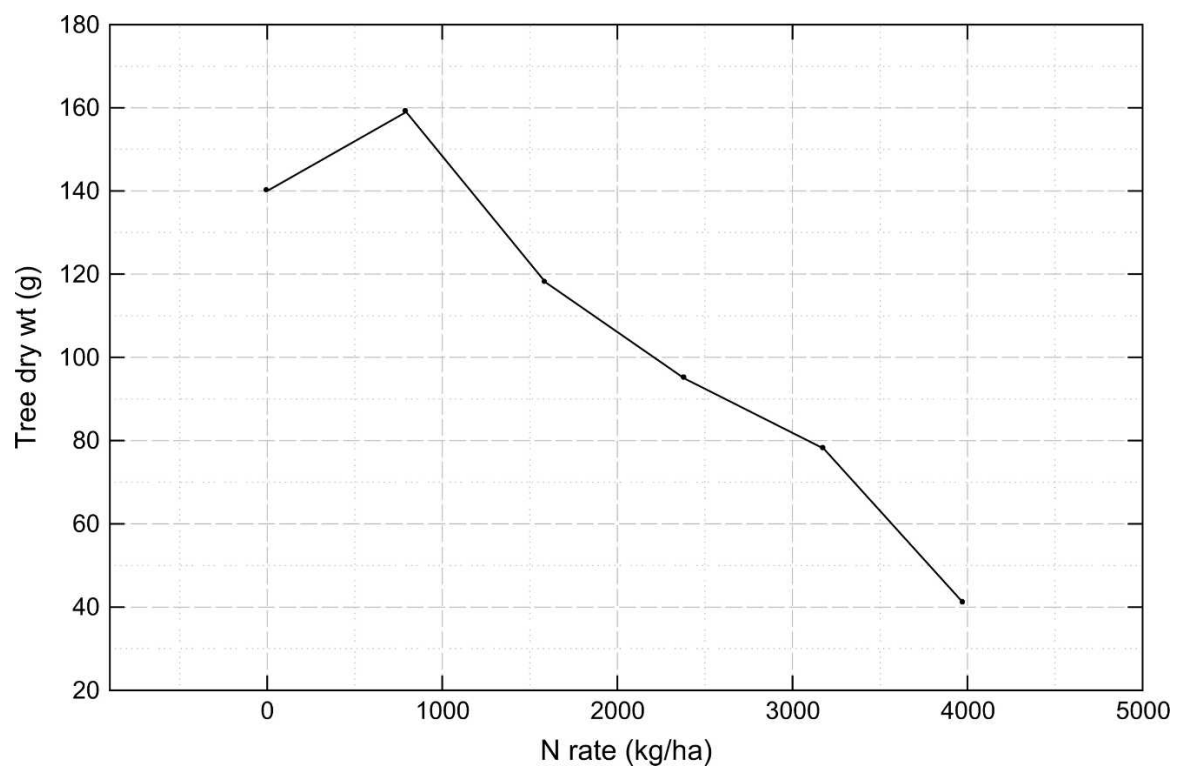

Fig. 2. Nitrogen $(\mathrm{N})$ rate effects on dry wt of 'Hamlin' orange trees in a field nursery in $1998(\mathrm{n}=12)$. Annual $\mathrm{N}$ rates are given in kilograms per treated hectare. $\mathrm{y}=140+0.45 \mathrm{x}+0.027 \mathrm{x}+0.0005 \mathrm{x}^{1.5}+-3.5 \mathrm{e}-06 \mathrm{x}^{2.5}, r^{2}=0.99$, $\mathrm{n}=12.1 \mathrm{~kg} \cdot \mathrm{ha}^{-1}=0.8922 \mathrm{lb} /$ acre; $1 \mathrm{~g}=0.0353 \mathrm{oz}$. 
of CLM by introduced Aegeniaspsis citicola. Glyphosate $\left(7.5 \mathrm{~g} \cdot \mathrm{L}^{-1}\right)$ was used for weed control. Microelements zinc, copper, boron, manganese, and iron were applied twice per

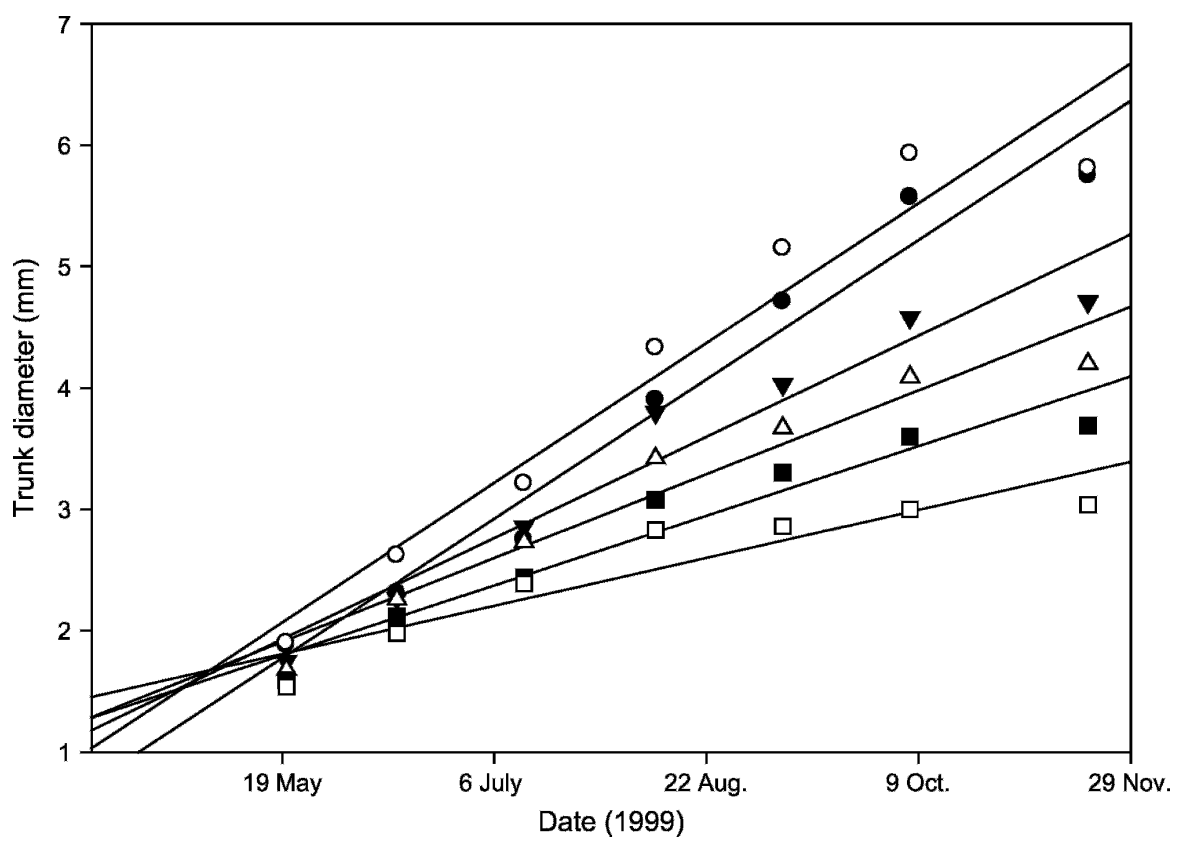

Fig. 3. Nitrogen $(\mathrm{N})$ rate effects on trunk diameter of 'Hamlin' orange trees in a field nursery in $1999(\mathrm{n}=12)$. Annual $\mathrm{N}$ rates are given in kilograms per treated hectare. ( $\square), 0 \mathrm{~kg} \cdot \mathrm{ha}^{-1} \mathrm{~N}, \mathrm{y}=1.77+0.023 \mathrm{x}, r^{2}=0.96 ;(\bigcirc), 794 \mathrm{~kg} \cdot \mathrm{ha}^{-1} \mathrm{~N}$, $\mathrm{y}=2.06+0.023 \mathrm{x}, r^{2}=0.94 ;(\nabla), 1589 \mathrm{~kg} \cdot \mathrm{ha}^{-1} \mathrm{~N}, \mathrm{y}=1.93+0.017 \mathrm{x}, r^{2}=0.95$; $(\triangle), 2384 \mathrm{~kg} \cdot \mathrm{ha}^{-1} \mathrm{~N}, \mathrm{y}=1.91+0.014 \mathrm{x}, r^{2}=0.95 ;(\bullet), 3179 \mathrm{~kg} \cdot \mathrm{ha}^{-1} \mathrm{~N}$, $\mathrm{y}=1.80+0.11 \mathrm{x}, r^{2}=0.94 ;(\square), 3976 \mathrm{~kg} \cdot \mathrm{ha}^{-1} \mathrm{~N}, \mathrm{y}=1.81+0.008 \mathrm{x}$, $r^{2}=0.85$. $\left(1 \mathrm{~kg} \cdot \mathrm{ha}^{-1}=0.8922 \mathrm{lb} /\right.$ acre; $\left.1 \mathrm{~mm}=0.0394 \mathrm{inch}\right)$.

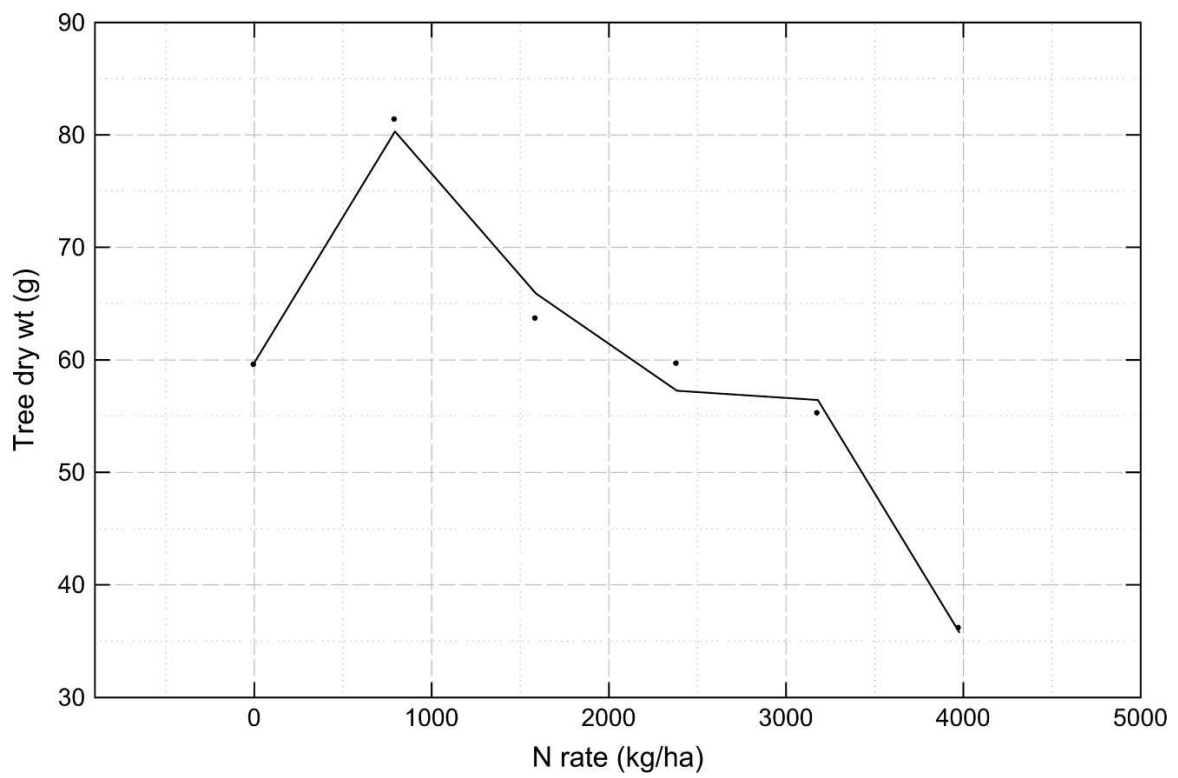

Fig. 4. Nitrogen $(\mathrm{N})$ rate effects on dry weight of 'Hamlin' orange trees in a field nursery in $1999(\mathrm{n}=12)$. Annual $\mathrm{N}$ rates are given in kilograms per treated hectare. $\mathbf{y}=7.72+0.004 x+5.08 x^{2}+1.86 x^{3}+2.25 \mathrm{e}-13 x^{4}, r^{2}=0.98, n=12$.

$\left(1 \mathrm{~kg} \cdot \mathrm{ha}^{-1}=0.8922 \mathrm{lb} /\right.$ acre; $\left.1 \mathrm{~g}=0.0353 \mathrm{oz}\right)$.

\section{Results and discussion}

SEASON 1. Repeated-measures analysis showed a highly significant time, treatment ( $\mathrm{N}$ rate), and time $\times$ treatment effect (data not shown) for trunk diameter $(P<0.001)$. Trunk diameters were similar for all treatments at the beginning of the experiment, but by 1 month after planting, trees receiving the $794-\mathrm{kg} \cdot \mathrm{ha}^{-1}$ annual $\mathrm{N}$ rate had significantly greater $(P<$ 0.05 ) trunk diameters than those receiving the two highest annual $\mathrm{N}$ rates (3179 and $3976 \mathrm{~kg} \cdot \mathrm{ha}^{-1}$; Fig. 1). This trend continued for the remainder of the season until 2 Dec. There was a highly significant linear increase in trunk diameter during the course of the study for all treatments, although the growth rate approached zero from November to December, as observed previously for young citrus trees in the field (Davies and Zalman, 2000).

Tree dry weight at the end of the year increased as $\mathrm{N}$ rate increased from 0 to $794 \mathrm{k} \cdot \mathrm{ha}^{-1}$ and then decreased linearly with increasing $\mathrm{N}$ rate thereafter (Fig. 2). Maximum dry weight occurred at the $794 \mathrm{~kg} \cdot \mathrm{ha}^{-1}$ annual $\mathrm{N}$ rate. Tree heights were similar for all $\mathrm{N}$ rates at harvest as a result of pruning and there were no consistent seasonal trends related to treatment (data not shown).

SEAsON 2. Repeated-measures analysis again showed a highly significant time, treatment ( $\mathrm{N}$ rate), and time $\times$ treatment effect (data not shown; $P<0.001$ ). Trunk diameters were similar across treatments on 19 May with the $794-\mathrm{kg} \cdot \mathrm{ha}^{-1} \mathrm{~N}$ rate separating $(P<0.05)$ from the two highest rates by 16 June (Fig. 3 ), and continuing that way until 29 Nov. There was a significant linear correlation between $\mathrm{N}$ rate and trunk diameter, and the y-intercept points were similar for all $\mathrm{N}$ rates. The slopes of the lines, however, differed greatly among $\mathrm{N}$ rates, with the $794 \mathrm{-kg} \cdot \mathrm{ha}^{-1}$ rate having the greatest slope (highest trunk growth rate).

Tree dry weight at the end of May 2000 increased from 0 to 794 $\mathrm{kg} \cdot \mathrm{ha}^{-1}$, then reached a plateau at the three intermediate rates and decreased sharply at the $3976-\mathrm{kg} \cdot \mathrm{ha}^{-1}$ annual rate (Fig. 4). Maximum dry weight again occurred at the 794$\mathrm{kg} \cdot \mathrm{ha}^{-1}$ annual $\mathrm{N}$ rate. Tree heights were similar among treatments as a 
result of pruning and there were no seasonal trends related to treatment (data not shown).

LEAF NITROGEN. Leaf $\mathrm{N}$ concentration increased linearly from 794 to $2384 \mathrm{~kg} \cdot \mathrm{ha}^{-1}$, but decreased at the highest $\mathrm{N}$ rate in 1998 (Fig. 5). In 1999 , leaf $\mathrm{N}$ again increased linearly

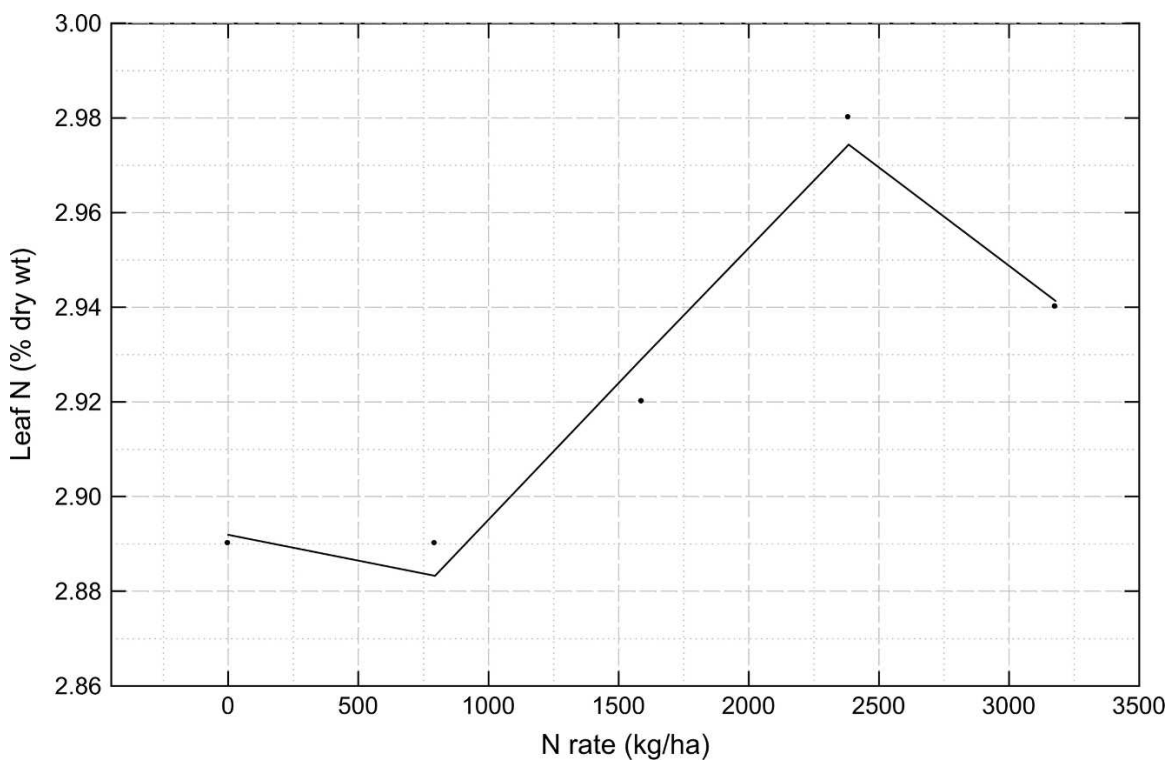

Fig. 5. Nitrogen $(\mathrm{N})$ rate effects on leaf $\mathrm{N}$ concentration of 'Hamlin' orange trees in the field in $1998(\mathrm{n}=$ the mean of six leaves per replicate for 12 replications per treatment). Annual $\mathrm{N}$ rates are given in kilograms per treated hectare. $\mathrm{y}=\mathbf{2 . 8 9}+$ $4.87 \mathrm{x}+3.02 \mathrm{e}-09 \mathrm{x}^{2.5}+4.72 \mathrm{e}-11 \mathrm{x}^{3}, r^{2}=0.97$. Treatment $4\left(2384 \mathrm{~kg} \cdot \mathrm{ha}^{-1} \mathrm{~N}\right)$ was not included in the regression because the mean leaf $\mathrm{N}$ concentration was significantly outside the other values. $\left(1 \mathrm{~kg} \cdot \mathrm{ha}^{-1}=0.8922 \mathrm{lb} / \mathrm{acre}\right)$.

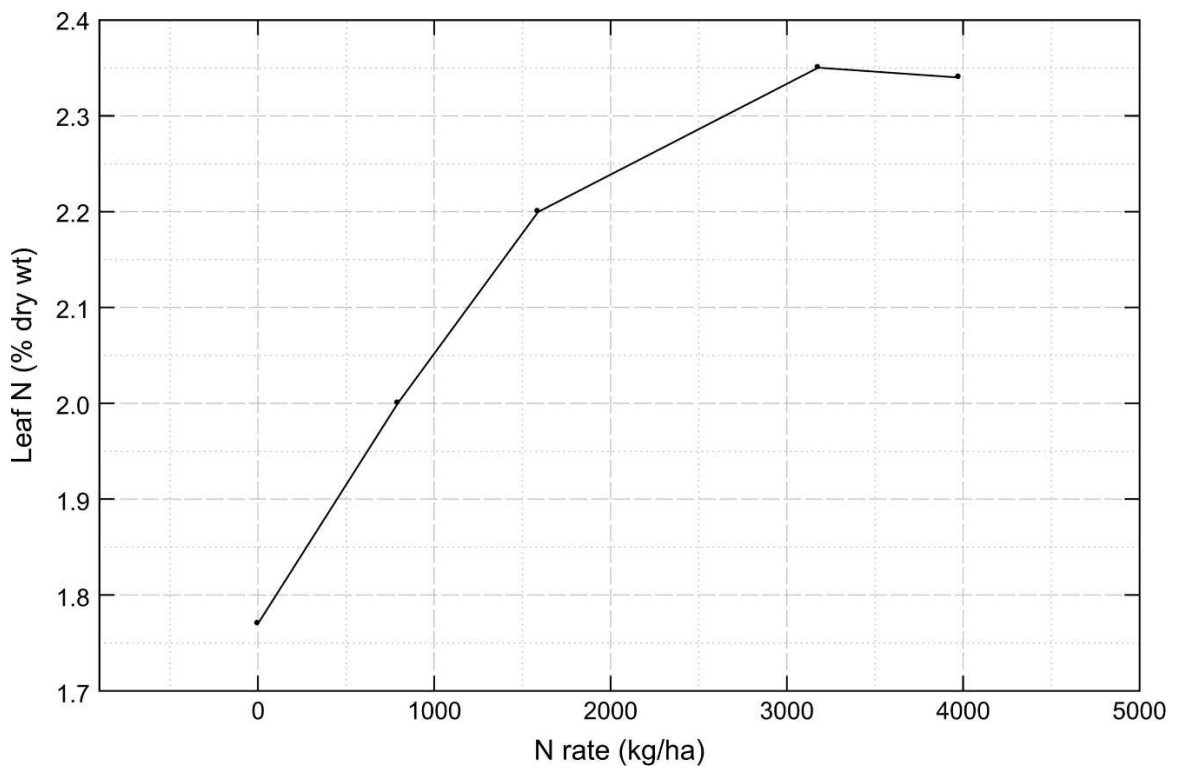

Fig. 6. Nitrogen $(N)$ rate effects on leaf $N$ concentration of 'Hamlin' orange trees in a field nursery in 1999 ( $n$ = the mean of six leaves per replicate for 12 replications per treatment). Annual $\mathrm{N}$ rates are given in kilograms per treated hectare; $\mathrm{y}=1.41+$ $2.69 \mathrm{e}-8 \mathrm{x}^{2}+0.021 \mathrm{x}^{0.5}+0.35 \mathrm{e}^{-\mathrm{x}}, r^{2}=0.99$. Treatment $4\left(2384 \mathrm{~kg} \cdot \mathrm{ha}{ }^{-1} \mathrm{~N}\right)$ was not included in the regression because the mean leaf $\mathrm{N}$ concentration was significantly outside the other values. $\left(1 \mathrm{~kg} \cdot \mathrm{ha}^{-1}=0.8922 \mathrm{lb} / \mathrm{acre}\right)$. seasons and very predictive of $\mathrm{N}$ application rate except at the highest rates. Nevertheless, leaf $\mathrm{N}$ concentration was not a good predictor of tree dry weight $\left(r^{2}=0.60\right.$ and 0.27 during seasons 1 and 2 respectively).

Surveys of $\mathrm{N}$ application rates in the Florida citrus industry suggested that a wide range of rates are used in field nurseries (Castle and Rouse, 1990). Our study suggests that annual $\mathrm{N}$ rates more than $794 \mathrm{~kg}$ per treated hectare may actually decrease tree trunk diameter and dry weight in an Arredondo fine sand, although the two highest rates were considerably more than those used commercially. However, our preexperiment hypothesis was that optimum $\mathrm{N}$ rate would occur in the 1200 to $1500-\mathrm{kg} \cdot \mathrm{ha}^{-1}$ range based on previous recommendations, and therefore the two higher rates were included in the study. Maust and Williamson (1991) also found that high $\mathrm{N}$ rates decreased growth of citrus trees in the greenhouse. Our results were very similar in both years of the study, even though two different sources of liners with differing initial sizes and leaf $\mathrm{N}$ concentrations were used. Similarly, Guazzelli et al. (1995) observed that initial leaf $\mathrm{N}$ concentration in the nursery had no effect on subsequent tree growth in the field and that leaf $\mathrm{N}$ concentration was not necessarily correlated with tree growth.

\section{Conclusion}

A wide range of $\mathrm{N}$ rates was applied to 'Hamlin' orange trees in two field nurseries during two seasons. Tree growth as measured by trunk diameter, which is an important factor to citrus nursery growers, and dry weight were greatest at the 794$\mathrm{kg} \cdot \mathrm{ha}^{-1}$ annual rate, and growth rate and dry weights decreased at rates more than $1589 \mathrm{~kg} \cdot \mathrm{ha}^{-1}$ annually. Our data are in agreement with previously recommended, but not experimentally determined, ranges of optimum $\mathrm{N}$ rates for citrus field nurseries in Florida (Tucker and Youtsey, 1980), but suggest that very high $\mathrm{N}$ rates may actually reduce tree size. Leaf $\mathrm{N}$ concentration varied yearly with nursery tree source and correlated well with $\mathrm{N}$ rate except at the highest rates, but was not predictive of tree trunk diameter or dry weight. The optimum $\mathrm{N}$ rate in an Arredondo 
fine sand in this study may vary from that in other soil types.

\section{Literature cited}

Bridges, G.D. and C.O. Youtsey. 1977. Cultural practices in Florida citrus nurseries. Proc. Intl. Soc. Agr. 1:121-124.

Castle, W.S. and R.E. Rouse. 1990. Total mineral nutrient content of Florida citrus nursery plants. Proc. Fla. State Hort. Soc. 103:42-43.

Davies, F.S. and G. Zalman. 2000. Irrigation scheduling and growth of young Hamlin orange trees. Proc. Fla. State Hort. Soc. 113:53-57.
Guazzelli, L., F.S. Davies, J.J. Ferguson, and W.S. Castle. 1995. Nitrogen nutrition and growth of Hamlin orange nursery trees on Swingle citumelo rootstock. HortTechnology 5:147-149.

Guazzelli, L., J.J. Ferguson, and F.S. Davies. 1996. Pre-plant leaf nitrogen effects on growth and fertilizer requirement of young 'Hamlin' orange trees. Proc. Fla. State Hort. Soc. 109:72-76.

Kessinger, M. 2005. Bureau of budwood registration. Div. Plant Ind., Ann. Rpt., Florida Dept. Agr., Winter Haven, FL.

Marler, T.E. and F.S. Davies. 1990.

Microsprinkler irrigation and growth of young Hamlin orange trees. J. Amer. Soc. Hort. Sci. 115:45-51.

Maurer, M.A. and F.S. Davies. 1995. Reclaimed wastewater irrigation and fertilization of mature 'Redblush' grapefruit trees on spodosols in Florida. J. Amer. Soc. Hort. Sci. 102:394-402.

Maust, B.E. and J.G. Williamson. 1991. Nitrogen rate effect on growth of containerized citrus nursery plants. Proc. Fla. State Hort. Soc. 104:191-195.

Tucker, D.P.H. and C.O. Youtsey. 1980. Citrus nursery practices. Florida Coop. Ext. Ser. Cir. 430, University of Florida, Gainesville. 